\title{
Crizotinib-induced osteitis mimicking bone metastasis in a stage IV ALK-rearranged NSCLC patient: a case report
}

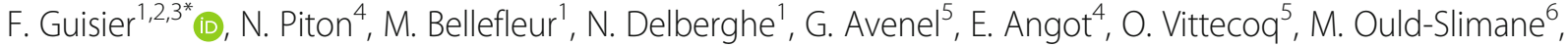
H. Morisse-Pradier ${ }^{1}$, M. Salaun ${ }^{1,2,3}$ and L. Thiberville ${ }^{1,2,3}$

\begin{abstract}
Background: Targeted therapies are a standard of care for first-line treatment of Anaplastic lymphoma kinase (ALK)rearranged non small cell lung cancer (NSCLC). Giving the rapid pace of drug discovery and development in this area, reporting of adverse effects of ALK inhibitors is crucial. Here, we report a case of osteitis induced by an ALK inhibitor mimicking bone metastasis, a previously undescribed side effect of crizotinib.

Case presentation: A 31-year-old woman with stage IV ALK-rearranged NSCLC presented with back pain after 3 months of crizotinib treatment. Diagnostic work-up showed osteitis on the 4th and 5th thoracic vertebrae, anterior soft tissue infiltration and epiduritis, without any sign of infection. Spinal cord decompression, histological removal and osteosynthesis were performed. Histologic examination showed necrosis with abundant peripheral neutrophils, no microorganism nor malignant cell. Symptoms and Computarized Tomography-abnormalities rapidly diseappeared after crizotinib withdrawal and did not recur after ceritinib onset.

Conclusions: This is the first report of crizotinib-induced osteitis. Crizotinib differs from other ALK inhibitors as it targets other kinases as well, which may have been responsible for the osteitis. Crizotinib can induce rapidly extensive osteitis, which can mimic tumor progression.
\end{abstract}

Keywords: ALK-rearranged NSCLC, ALK inhibitors, Crizotinib, Ceritinib, Drug toxicity, Osteitis

\section{Background}

About $3-5 \%$ of non small cell lung cancer (NSCLC) harbor Anaplastic lymphoma kinase $(A L K)$-rearrangement, mainly with echinoderm microtubule-associated proteinlike $4(E M L 4)$ as a gene partner. The resulting fusion protein is constitutively activated and shows oncogenic properties [1]. Multiple ALK inhibitors are now available and were shown to improve patient outcomes [2-6]. The first ALK inihibitor to be approved was crizotinib, a small molecule tyrosine kinase inhibitor [7], which was the standard first-line treatment of patients with $A L K$ rearranged advanced NSCLC [8]. Ceritinib and alectinib are other ALK inhibitors available in several countries and alectinib is considered the new standard of care.

\footnotetext{
* Correspondence: florian.guisier@chu-rouen.fr

1 Service de pneumologie, oncologie thoracique et soins intensifs respiratoires, CHU Charles Nicolle, Rouen, France

${ }^{2}$ LITIS QuantIF EA4108, Normadie Univ, Rouen, France

Full list of author information is available at the end of the article
}

Lorlatinib is also available in Japan [9] and brigatinib in the USA [10].

Crizotinib toxicity profile consists mainly in moderate visual disorders, electrocardiogram modification (mainly sinus bradycardia and QT interval prolongation), nausea, vomiting, diarrhea, liver enzyme elevation, fatigue, peripheral oedema, neutropenia and esophagitis [11, 12]. Here, we report the case of a previously undescribed side effect of crizotinib.

\section{Case presentation}

A 31-year-old woman with metastatic $A L K$ rearranged NSCLC was referred to our center. There was no bone lesion at this time, neither on Computarized Tomography (CT)-scan nor on Fluoro-Desoxy-Glucose (FDG) Positron-EmissionTopmography (PET) scan. Crizotinib treatment was initiated as first line, with dramatic radiological response and rapid decrease of blood

(c) The Author(s). 2020 Open Access This article is distributed under the terms of the Creative Commons Attribution 4.0 International License (http://creativecommons.org/licenses/by/4.0/), which permits unrestricted use, distribution, and reproduction in any medium, provided you give appropriate credit to the original author(s) and the source, provide a link to the Creative Commons license, and indicate if changes were made. The Creative Commons Public Domain Dedication waiver (http://creativecommons.org/publicdomain/zero/1.0/) applies to the data made available in this article, unless otherwise stated. 


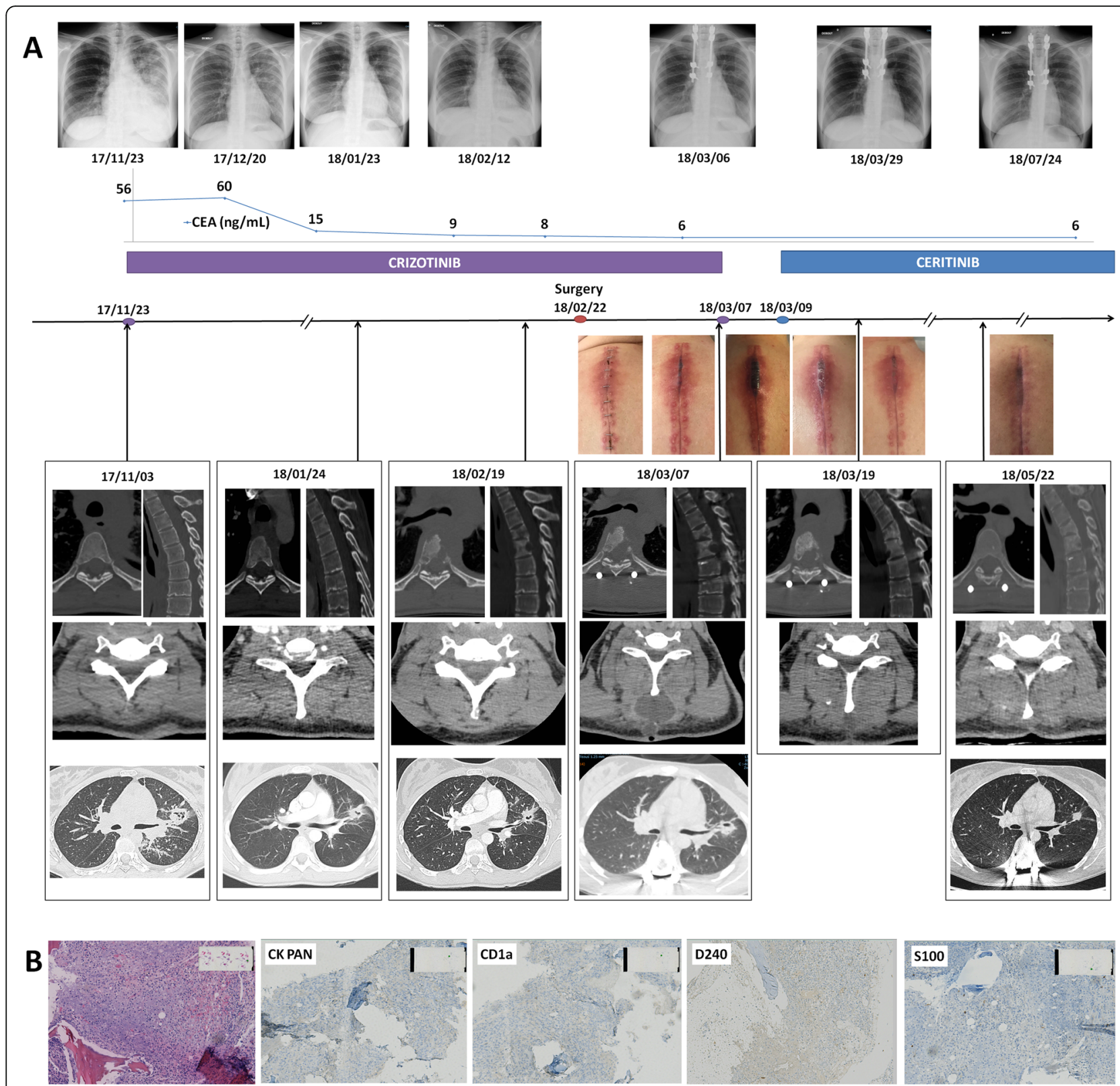

Fig. 1 A necrotic bone lesion mimicking bone metastasis. a Chronology of treatments, CT-scan and MRI findings and photographs of the surgical suture. b Representative imaging of HES coloration and pan-cytokeratine, CD1a, D2-40 and PS100 immunostains of the bone biopsy sample

carcinoembryonic antigen (CEA) from 60 ng.mL-1 to 9 in 6 weeks (Fig. 1). Three months after crizotinib treatment onset, the patient presented with back pain, without neurologic disorder. She reported neither trauma nor pyrexia. She received no other medication during the previous 3 months. FDG-PET/CT scan revealed a hypermetabolic lesion on the 4th and 5th thoracic (Th4 and Th5) vertebrae. Spine Magnetic Resonnance Imaging (MRI) and CT-scan showed Th4 and Th5 vertebrae osteitis, anterior soft tissue infiltration and epiduritis. MRI T1 signal was highly enhanced after Gadolinium injection. Th4-Th5 spinal disc was intact. C
Reactive Protein (CRP) level was 41 mg.L-1, white-blood cell count was normal, blood cultures were sterile, and CEA blood level remained at its lowest.

Because of the rapid extension of both osteitis and paravertebral collection that jeopardized spine stability, spinal cord decompression associated with histological removal and osteosynthesis were performed, by a posterior approach. Histological examination showed necrosis with abundant peripheral neutrophils, no microorganism nor malignant cell. Ziehl coloration was negative. Negativity of PS100 and CD1a immunostains eliminated Langherans cell histioctyosis. The absence of lymphatic 
vessel proliferation eliminated Gorham syndrome. Cultures of biopsy samples and Polymerase Chain Reaction (PCR) assays, including ribosomal $16 \mathrm{~S}$ sequencing and mycobacterium complex PCR assay, remained negative. A week after surgery, severe inflammation and necrosis of the cutaneous surgical suture appeared, with subcutaneous and paravertebral soft tissue infiltration confirmed on CT-scan.

Because of the absence of tumour cell or germ on biopsy samples, crizotinib-induced osteitis was suspected. A retrospective review of the first chest CT-scan performed for assessment of tumor response to crizotinib 2 months after treatment initiation showed early signs of osteitis on the Th4 vertebra (Fig. 1). Crizotinib was suspended. The patient did not receive antibiotics. Subcutaneous inflammation regressed after 2 days. Ceritinib was initiated 2 days later. CT-scan at 2 weeks showed regression of osteitis and soft tissue infiltration. After 12 months, the patient is still on ceritinib, without any new lesion.

\section{Discussion and conclusions}

Vertebral osteitis in a patient with stage IV cancer is commonly attributed to bone metastasis when infection has been ruled out. Nevertheless some differential diagnostic exist. Giving the fact that median overall survival in $A L K$-rearranged NSCLC reaches 4 years and even up to 81 months in the literature $[13,14]$, we believed that an invasive procedure was legitimate to rule out these differential diagnostic. In our patient's case, diagnostic work-up ruled out an infectious osteitis, including tuberculosis. Several points made us confident that there was no bone metastasis: (i) the absence of malignant cell on surgical biopsies, (ii) the rapid regression of paravertebral collection after crizotinib withdrawal, before ceritinib treatment onset, (iii) the normal CEA blood level at the time of rapidly extensive bone and soft tissue lesion, while CEA blood level was elevated at the time of diagnosis and rapidly decreased thereafter. CEA use is not a recommended biomarker in NSCLC but was monitored in our patient. Other causes of osteitis have also been ruled out through histology and immunostainings analysis. Of note, unlike in Gorham's vanishing bone syndrome or aneurysmal bone cysts, no marker of vascular proliferation or fibrosis was seen, suggesting a different entity. Lastly, non-specific inflammation cannot be ruled out, by definition. Nevertheless, the sequence of lesion improvement after crizotinib discontinuation support our hypothesis of a crizotinib-induced osteitis. Crizotinib is known to induce renal, pancreatic and liver cysts [8$12,15,16]$. To our knowledge no crizotinib-induced osteitis has been reported to date.

Crizotinib differs from other ALK inhibitors as it potently inhibits other kinases, which may have been responsible for the osteitis. The favourable outcome despite ceritinib treatment is consistent with this hypothesis. Of note, crizotinib inhibits MET proto-oncogene (MET) and Macrophage Stimulating Factor 1 Receptor (MST1R, also peviously known as RON), two receptors that regulate osteogenesis through Platelet Derived Growth Factor (PDGF). PDGF pathway is thought to be involved in sorafenib- and imatinib- induced osteonecrosis by reducing the activity of osteoclastogenic cytokines including macrophage colonystimulating factor (M-CSF) and receptor activator of nuclear factor kappa-B ligand (RANKL) [17]. PDGF signalling might have been involved in our patient's osteitis. Other drug-induced osteonecrosis mechanisms are known such as Cyclooxygenoase 2 inhibition by non-steroid anti-inflammatory drugs and nuclear factor of activated T-cells cytoplasmic 1 (NFATc1) inhibition by bisphosphonates [18]. Crizotinib as no direct interaction with these pathways.

Crizotinib can induce rapidly extensive osteitis, which can mimic tumor progression. In our patient's case, osteitis regressed after Crizotinib withdrawal and did not recur under ceritinib treatment.

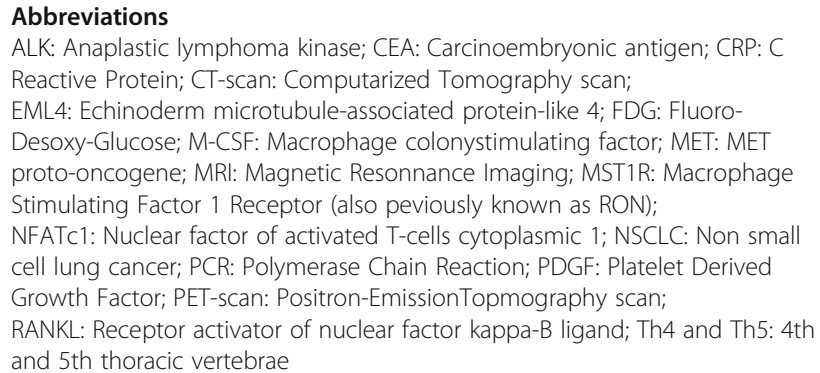

\section{Acknowledgements}

We thank the patient in this report. We are indebted to Nikki Sabourin-Gibbs, Rouen University Hospital, for her help in editing the manuscript.

\section{Authors' contributions}

FG, NP, MB, ND, GA, EA, OV, MOS, HMP, MS and LT were involved in the clinical management of the patient and made substantial contributions to the acquisition, analysis and interpretation of data. FG, NP, ND, HMP, MS and LT wrote the manuscript. FG, NP, MB, ND, GA, EA, OV, MOS, HMP, MS and LT revised the manuscript and approved its final version. FG, NP, MB, ND, GA, EA, OV, MOS, HMP, MS and LT have approved the submitted version and have agreed both to be personally accountable for their own contributions and to ensure that questions related to the accuracy or integrity of any part of the work, even ones in which they were not personally involved, are appropriately investigated, resolved, and the resolution documented in the literature.

\section{Funding}

none.

\section{Availability of data and materials} Not applicable.

Ethics approval and consent to participate Not applicable. 


\section{Consent for publication}

A written informed consent has been provided by the patient to have the case details and any accompanying images published.

\section{Competing interests}

FG reports personal fees BMS, MSD/MERCK US, ASTRA ZENECA, BOEHRINGER INGELHEIM and ROCHE, and non-financial support from BMS, BOEHRINGER INGELHEIM, CHUGAI and PFIZER, outside the submitted work. $N P, M B, N D, G A, E A, O V, M O S, H M P, M S$ and LT have nothing to disclose.

\section{Author details}

${ }^{1}$ Service de pneumologie, oncologie thoracique et soins intensifs respiratoires, CHU Charles Nicolle, Rouen, France. ${ }^{2}$ LITIS QuantIF EA4108, Normadie Univ, Rouen, France. ${ }^{3}$ INSERM CIC 1404, CHU Charles Nicolle, Rouen, France. ${ }^{4}$ Service d'anatomie et cytologie pathologiques, CHU Charles Nicolle, Rouen, France. ${ }^{5}$ Service de rhumatologie, CHU Charles Nicolle, Rouen, France. ${ }^{6}$ Service d'orthopédie et traumatologie, CHU Charles Nicolle, Rouen, France.

Received: 8 March 2019 Accepted: 20 December 2019

Published online: 06 January 2020

\section{References}

1. Soda M, Choi YL, Enomoto M, Takada S, Yamashita Y, Ishikawa S, et al. Identification of the transforming EML4-ALK fusion gene in non-small-cell lung cancer. Nature. 2007:448(7153):561-6.

2. Shaw AT, Kim D-W, Nakagawa K, Seto T, Crino L, Ahn M-J, et al. Crizotinib versus chemotherapy in advanced ALK-positive lung cancer. N Engl J Med. 2013;368(25):2385-94.

3. Hida T, Nokihara H, Kondo M, Kim YH, Azuma K, Seto T, et al. Alectinib versus crizotinib in patients with ALK-positive non-small-cell lung cancer (JALEX): an open-label, randomised phase 3 trial. Lancet. 2017;390(10089):2939.

4. Peters S, Camidge DR, Shaw AT, Gadgeel S, Ahn JS, Kim DW, et al. Alectinib versus Crizotinib in untreated ALK-positive non-small-cell lung Cancer. N Engl J Med. 2017;377(9):829-38.

5. Soria J-C, Tan DSW, Chiari R, Wu Y-L, Paz-Ares L, Wolf J, et al. First-line ceritinib versus platinum-based chemotherapy in advanced ALK-rearranged non-small-cell lung cancer (ASCEND-4): a randomised, open-label, phase 3 study. Lancet. 2017;389(10072):917-29.

6. Camidge DR, Kim HR, Ahn M-J, Yang JC-H, Han J-Y, Lee J-S, et al. Brigatinib versus Crizotinib in ALK-positive non-small-cell lung cancer. N Engl J Med. 2018;379(21):2027-39.

7. Zou HY, Li Q, Lee JH, Arango ME, McDonnell SR, Yamazaki S, et al. An orally available small-molecule inhibitor of c-met, PF-2341066, exhibits cytoreductive antitumor efficacy through antiproliferative and antiangiogenic mechanisms. Cancer Res. 2007;67(9):4408-17.

8. Hanna N, Johnson D, Temin S, Baker SJ, Brahmer J, Ellis PM, et al. Systemic therapy for stage IV non-small-cell lung cancer: American society of clinical oncology clinical practice guideline update. J Clin Oncol. 2017;35(30):3484515.

9. Solomon BJ, Besse B, Bauer TM, et al. Lorlatinib in patients with ALK-positive non-small-cell lung cancer: results from a global phase 2 study. Lancet Oncol. 2018;19:1654-67.

10. Huber RM, Hansen KH, Paz-Ares Rodríguez L, West HL, et al. Brigatinib in Crizotinib-refractory ALK+ non-small cell lung Cancer: 2-year follow-up on systemic and intracranial outcomes in the phase 2 ALTA trial. J Thorac Oncol. 2019. (In Press).

11. Cappuzzo F, Moro-Sibilot D, Gautschi O, Boleti E, Felip E, Groen HJM, et al. Management of crizotinib therapy for ALK-rearranged non-small cell lung carcinoma: an expert consensus. Lung Cancer. 2015;87(2):89-95.

12. Srivastava N, VanderLaan PA, Kelly CP, Costa DB. Esophagitis: a novel adverse event of crizotinib in a patient with ALK-positive non-small-cell lung cancer. J Thorac Oncol. 2013;8(3):e23-4.

13. Pacheco JM, Gao D, Smith D, Purcell T, Hancock M, Bunn P, et al. Natural history and factors associated with overall survival in stage IV ALKrearranged non-small cell lung Cancer. J Thorac Oncol. 2019;14(4):691-700.

14. Johung KL, Yeh N, Desai NB, Williams TM, Lautenschlaeger T, Arvold ND, et al. Extended survival and prognostic factors for patients with ALKrearranged non-small-cell lung Cancer and brain metastasis. J Clin Oncol. 2016;34(2):123-9.
15. Halpenny DF, McEvoy S, Li A, Hayan S, Capanu M, Zheng J, et al. Renal cyst formation in patients treated with crizotinib for non-small cell lung cancerincidence, radiological features and clinical characteristics. Lung Cancer. 2017:106:33-6.

16. Ishida H, Ichikawa W, Sasaki Y. Crizotinib-induced pancreatic pseudocyst: a novel adverse event. BMJ Case Rep. 2015;2015:bcr2015211556.

17. Nifosì AF, Zuccarello M, Nifosì L, Hervas Saus V, Nifosì G. Osteonecrosis of the jaw in the era of targeted therapy and immunotherapy in oncology. J Korean Assoc Oral Maxillofac Surg. 2019;45(1):3-8.

18. Anesi A, Generali L, Sandoni L, Pozzi S, Grande A. From osteoclast differentiation to osteonecrosis of the jaw: molecular and clinical insights. Int J Mol Sci. 2019;20(19):4925.

\section{Publisher's Note}

Springer Nature remains neutral with regard to jurisdictional claims in published maps and institutional affiliations.
Ready to submit your research? Choose BMC and benefit from:

- fast, convenient online submission

- thorough peer review by experienced researchers in your field

- rapid publication on acceptance

- support for research data, including large and complex data types

- gold Open Access which fosters wider collaboration and increased citations

- maximum visibility for your research: over $100 \mathrm{M}$ website views per year

At BMC, research is always in progress.

Learn more biomedcentral.com/submissions 